\begin{abstract}
The aim of this study was to estimate the age and growth parameters of the Panamic stingray (Urotrygon aspidura) of the Pacific coast of Colombia. Vertebral centra were removed from 309 individuals and used for estimation of age. The results of edge type and marginal increment analysis indicate an annual formation of band pairs. The maximum ages estimated were 7.5 and 5.5 years for female and male Panamic stingrays, respectively. Individual growth was described through a multi-model approach and inference, by using von Bertalanffy, Gompertz, and logistic models with 2 and 3 parameters each and a two-phase growth model with 4 and 5 parameters. A two-phase growth function of 5 parameters with adjusted age provided the best description of growth for females (asymptotic disc width $\left[D W_{\infty}\right]=24.71 \mathrm{~cm}$, growth coefficient $[k]=0.47 \mathrm{~cm} /$ year, disc width at birth $\left[D W_{0}\right]=8.18 \mathrm{~cm}$, age at transition between 2 phases $\left[t_{\mathrm{h}}\right.$ or inflection point of the curve]=2.32 years, and maximum difference in disc width at age between von Bertalanffy and two-phase models $[h]=0.36)$ and males $\left(D W_{\infty}=15.96 \mathrm{~cm}\right.$, $k=1.63 \mathrm{~cm} /$ year, $D W_{0}=8.07 \mathrm{~cm}, t_{\mathrm{h}}=$ 2.22 years, $h=0.54)$. The growth curves were dissimilar between sexes mainly after the inflection point, and differences were found for all parameters, except for $t_{\mathrm{h}}$. The Panamic stingray is a fast-growing and short-lived elasmobranch, similar to other species of the Urotrygonidae.
\end{abstract}

Manuscript submitted 24 October 2018. Manuscript accepted 16 July 2019. Fish. Bull. 117:169-179 (2019). Online publication date: 30 July 2019. doi: 10.7755/FB.117.3.4

The views and opinions expressed or implied in this article are those of the author (or authors) and do not necessarily reflect the position of the National Marine Fisheries Service, NOAA.

\title{
Age and growth parameters of the Panamic stingray (Urotrygon aspidura)
}

\author{
Katherine Torres-Palacios (contact author) ${ }^{1,3}$ \\ Paola A. Mejía-Falla ${ }^{1,2}$ \\ Andrés F. Navia ${ }^{1}$ \\ Víctor H. Cruz-Escalona ${ }^{3}$ \\ Roberto Félix-Uraga ${ }^{3}$ \\ Casimiro Quiñonez-Velázquez ${ }^{3}$
}

Email address for contact author: ktorres@squalus.org

${ }^{1}$ Fundación Colombiana para la Investigación y Conservación de Tiburones y Rayas SQUALUS

Calle 10A \#72-35

Apartamento $310 \mathrm{E}$

760033 Cali, Valle del Cauca, Colombia

${ }^{2}$ Wildlife Conservation Society Colombia

Avenida $5 \mathrm{~N} \# 22 \mathrm{~N}-11$

760046 Cali, Valle del Cauca, Colombia

${ }^{3}$ Centro Interdisciplinario de Ciencias Marinas

Instituto Politécnico Nacional

Avenida Instituto Politécnico Nacional $s / n$

Colonia Playa Palo de Santa Rita

Apartado Postal 592

23096 La Paz, Baja California Sur, Mexico

Understanding the growth, age, maturation processes, and longevity of elasmobranch species is necessary to evaluate population status and to predict variations over time (Cailliet and Goldman, 2004), as well as to develop management and conservation initiatives (Harry et al., 2010; Smart et al., 2013). Rajiformes are the batoid group for which the greatest number of studies on age and growth have been carried out (Shark-References, vers. 2015, bibliography database available from website), mainly because of their size and commercial importance. Conversely, small species of no commercial importance, such as those belonging to the Urolophidae and Urotrygonidae (Order Myliobatiformes), have received less attention, despite being abundant bycatch in shrimp trawl fisheries (RicoMejía and Rueda, 2007; SantanderNeto, 2015; Clarke et al., 2016).
Age and growth studies for the Urotrygonidae, both in the American Pacific and Atlantic Oceans, have identified that species of the genus Urobatis (Babel, 1967; Hale and Lowe, 2008; Morales-Azpeitia et al., 2013; Smith et al., 2013; Spieler et al., 2013) as well as those of the genus Urotrygon (MejíaFalla et al., 2014; Guzmán-Castellanos, 2015; Santander-Neto, 2015) have high growth rates, low maximum ages, and early maturation, compared with other batoid species (Frisk, 2010) and with elasmobranchs in general (Cortés, 2000).

The Panamic stingray inhabits the Eastern Tropical Pacific (Robertson and Allen, 2015) and is abundant as bycatch in the shrimp trawl fishery of that region (Amezcua et al., 2006; Navia et al., 2009; Navarro-González et al., 2012). Despite its high incidence in this fishery, this species has been little studied with work done on only 
its diet (Navarro-González et al., 2012) and morphology (González-Isáis and Montes-Domínguez, 2016; MontesDomínguez and González-Isáis, 2017; Navarro-González et al., 2018). Consequently, it is categorized as a data deficient species in the International Union for Conservation of Nature IUCN Red List (Valenti and Robertson, 2009).

The high catch volumes of Panamic stingrays in the shrimp trawl fishery in the central zone of the Pacific coast of Colombia, the significant increase in the dominance of this species in the elasmobranch assemblage of the study area, the decrease in the catch rate (Navia and Mejía-Falla, 2016), and the lack of information on its life history traits highlight the importance of contributing relevant information for future population assessments. The aim of this study was to estimate and compare the age and growth parameters of male and female Panamic stingrays, by using a multi-model approach and inference.

\section{Material and methods}

\section{Specimen collection}

Individuals of the Panamic stingray were collected from an area of small-scale, shallow-water shrimp fishing operations in the central zone of the Pacific coast of Colombia (from $4^{\circ} 34^{\prime} \mathrm{N}, 77^{\circ} 21^{\prime} \mathrm{W}$ to $2^{\circ} 31^{\prime} \mathrm{N}, 78^{\circ} 34^{\prime} \mathrm{W}$ ), during 2006-2009 and 2015. The number of animals collected was lower during the first quarter of the year, given the closure of the shrimp trawl fishery in these months along the Pacific coast of Colombia. This area has sandy-muddy substrate and shallow (<8.3-m depth), warm (between $25^{\circ} \mathrm{C}$ and $29^{\circ} \mathrm{C}$ ), and brackish (salinity between 21.8 and 25.6) waters (Mejía-Falla, 2012).

Rays were measured (disc width [DW], in centimeters), their sex was determined, they were eviscerated, and part of the vertebral column from the abdominal region was extracted, tagged, and frozen until analysis was done later in the laboratory. Differences in DW between sexes were evaluated by using a Mann-Whitney test.

\section{Vertebrae processing and band-pair counts}

Vertebrae were cleaned manually by using a scalpel to eliminate the excess of muscle and connective tissue and to obtain the vertebral centra. The diameter of vertebrae was measured sagittally, and then the vertebrae were grouped in 3 size categories: large $(2.50-3.30 \mathrm{~mm})$, medium (1.60-2.49 $\mathrm{mm})$, and small $(0.70-1.59 \mathrm{~mm})$. Tests were carried out by using different thicknesses of cut, stains, and times of staining for each vertebra size. Vertebral sections were rinsed with distilled water and polished before being observed. The best combination for the visualization of bands was $0.4-\mathrm{mm}$ sagittal sections, stained with light green $(0.05 \%)$ for 5 min for small vertebrae and with methylene blue $(0.001 \%)$ for $10 \mathrm{~min}$ for medium vertebrae and for $20 \mathrm{~min}$ for large vertebrae. Sections were observed by using an optical microscope under transmitted light. Photographs were taken along with the respective scale by using the Zen lite ${ }^{1}$ (blue ed., vers. 1.0) microscope software for light microscopy systems (Carl Zeiss Microscopy, LLC, Jena, Germany), and the growth bands were measured along the border of the corpus calcareum of each vertebra, by using the Zen lite microscope software.

Two readers (reader 1 had the most experience) performed a training exercise of counting the bands of a subsample (sample size $[n]=100$ ) to refine the methods, identification criteria, and counts of translucent bands. The following criteria were established: 1) identification of the presence of a pair of growth bands (one translucent and one opaque), defined as a band pair; 2) identification of a birth band through a change in the angle of the corpus calcareum in the closest place to the focus of the vertebra; and 3) enumeration of translucent bands. The 2 readers then did an independent band count of the whole sample, without knowing the sex or size of the specimens. The translucent-band counts were compared, and if the band counts did not coincide between readings (with differences in band counts of 3 or more), a third reading was made to reach a consensus; if no consensus was reached, the sample was discarded.

\section{Bias and precision between readers}

Different methods were employed to evaluate bias and precision of readings, on the basis of independent readings (Cailliet and Goldman, 2004). The bias between readers was evaluated through an age-bias plot (Campana et al., 1995) and Bowker's test for symmetry (Hoenig et al., 1995). The age-bias plot relates the band-pair count of reader 1 (x-axis) versus the mean band-pair count of reader 2 (y-axis). The second test was used to evaluate whether differences between readings by reader 1 and 2 were due to random events $(P>0.05)$ or systematic errors $(P<0.05)$, by using a chi-square test.

The percentage of vertebrae that could be read was calculated as (number of read vertebrae/total number of samples $\times 100$. The percentage of agreement between readers was calculated as (number of agreements/total number of readings) $\times 100$, taking into account differences of 0,1 , and 2 band pairs.

The average percent error (APE) and the coefficient of variation (CV) between readers were also evaluated, taking into account variations of each reading with respect to the mean value of readings, as follows (Beamish and Fournier, 1981; Campana et al., 1995; Campana, 2001):

$$
A P E=\left[\frac{1}{n}\left(\frac{1}{R} \sum_{i=1}^{R} \frac{\left|\mathrm{x}_{\mathrm{ij}}-\overline{\mathrm{x}}_{\mathrm{j}}\right|}{\bar{x}_{\mathrm{j}}}\right)\right] \times 100 \text { and }
$$

\footnotetext{
${ }^{1}$ Mention of trade names or commercial companies is for identification purposes only and does not imply endorsement by the National Marine Fisheries Service, NOAA.
} 


$$
C V=\left[\frac{1}{n}\left(\frac{\sqrt{\sum_{i=1}^{R} \frac{\left(x_{\mathrm{ij}}-\bar{x}_{\mathrm{j}}\right)^{2}}{R}}}{\bar{x}_{\mathrm{j}}}\right)\right] \times 100
$$

where $x_{\mathrm{ij}}=$ the $i_{\mathrm{th}}$ reading for individual $j$;

$\bar{x}_{\mathrm{j}}=$ the average band-pair count for individual $j$;

$R=$ the number of readings (one for each reader); and

$n=$ the number of readings for the entire sample.

Low values of these indices indicate greater precision between readers (Campana, 2001).

\section{Periodicity in band-pair formation}

The periodicity in the formation of vertebral band pairs in Panamic stingrays was evaluated through the analysis of edge type (qualitative approach) and of the marginal increment (MI) index (quantitative approach). For the edge type, the band at the edge of each vertebra (opaque or translucent and growing or ending band) was identified, and the monthly frequency of each combination was calculated. The MI was estimated on the basis of the following measures taken of each vertebral sagittal section with the Zen lite microscope software: radius $(R$, or distance from the focus to the vertebral edge), and distance from the focus to the last $\left(R_{\mathrm{n}}\right)$ and next-to-last $\left(R_{\mathrm{n}-1}\right)$ completely formed band. The MI was estimated by using this equation: $M I=\left(R-R_{\mathrm{n}}\right) /\left(R_{\mathrm{n}}-R_{\mathrm{n}-1}\right)$ (Hayashi, 1976), and the average value was calculated and plotted per month. Differences in MIs among months were evaluated by using a Kruskal-Wallis test.

\section{Growth models and parameters}

Two data sets of age were built; the first considers the months with peaks of reproduction, and the second does not include this reproductive information (Harry et al., 2010; Mejía-Falla et al., 2014). In the first case (adjusted analysis), the time between birth and the first band formation was considered, on the basis of the reproductive cycle of the species obtaining a mean value for all data. Along the Pacific coast of Colombia, Panamic stingray present 2 birth peaks per year (in January and August; P. Mejía-Falla, unpubl. data), and the month of growth band formation occurs in October-November (see the "Results" section). Therefore, the times between birth and formation of the first growth band (9-10 or 2-3 months) have a mean of 6 months ( 0.5 years), a value that was subtracted from the total number of translucent bands counted. For the second data set, it was assumed that the first band pair is formed 1 year after birth, irrespective of reproductive seasonality; therefore, a value of 1 was subtracted from the total number of translucent bands counted. For example, an individual with 3 translucent bands counted had an age of 2.5 years for the first data set and an age of 2.0 years for the second data set.

A multi-model approach was used to describe growth. Eight models were fitted by using age and DW data of individuals: the von Bertalanffy growth model (VBGM; von Bertalanffy, 1938), Gompertz growth model (Ricker, 1979), and logistic growth model (Ricker, 1979) were fitted with 2 and 3 parameters, and the two-phase growth model (TPGM; Soriano et al., 1992) was fitted with 4 and 5 parameters (Suppl. Table 1). Models with 2 and 4 parameters include a $D W_{0}$ parameter, for which the birth DW at $7.5 \mathrm{~cm}$ was used (P. Mejía-Falla, unpubl. data). The parameter $D W_{\infty}$ is the theoretical asymptotic width, representing the average disc width at age that individuals in a stock would attain if they grew indefinitely. The annual $k$ is the relative growth rate at which a stingray reaches $D W_{\infty}$ at age. The parameter $t_{0}$ is the theoretical age at zero, a point on the time axis when mean DW at age is zero. Models with 4 and 5 parameters included $t_{\mathrm{h}}$, which is the age at which the transition between the 2 phases occurs (inflection point), and $h$ is the maximum difference in DW at age between the VBGM and the TPGM at the $t_{\mathrm{h}}$.

Parameters of the models were estimated by maximum likelihood method. The most adequate model was chosen on the basis of biological and statistical fit. Biological fit was based on known maximum DW, DW at birth, and DW at maturity $(26.5,7.5$, and $15 \mathrm{~cm}$ DW, respectively; P. MejíaFalla, unpubl. data). Statistical relevance was evaluated by calculating Akaike information criterion $\left(\mathrm{AIC}_{\mathrm{i}}\right.$, Akaike, 1973), as well as the difference in $\mathrm{AIC}_{\mathrm{i}}$ between models $\left(\Delta_{\mathrm{i}}\right)$ and Akaike weight $\left(w_{\mathrm{i}}\right)$, for each $i_{\text {th }}$ model, as follows:

$$
\begin{aligned}
A I C_{\mathrm{i}} & =2 \ln (L)+2 p, \\
\Delta_{\mathrm{i}} & =A I C_{\mathrm{i}}-A I C_{\min }, \text { and } \\
w_{\mathrm{i}} & =\frac{e^{\left(-0.5 \Delta_{\mathrm{i}}\right)}}{\sum e^{\left(-0.5 \Delta_{\mathrm{i}}\right)}},
\end{aligned}
$$

where $p=$ the number of parameters;

$L=$ maximum likelihood;

$\Delta_{\mathrm{i}}=$ the difference between each model's $\mathrm{AIC}_{\mathrm{i}}$; and

$A I C_{\text {min }}=$ the lowest $\mathrm{AIC}_{\mathrm{i}}$ of all models.

Models with $\Delta_{\mathrm{i}}$ values between 0 and 2 have substantial statistical support, those with values between 4 and 7 have moderate support, and those with values $>10$ have no support (Burnham and Anderson, 2002). With multimodel inference, if one model does not obtain an Akaike weight value over 0.9 or if several models have substantial statistical support, it is advisable to estimate a weighted average of parameters on the basis of the models with support, along with the associated unconditional standard error (SE) (Burnham and Anderson, 2002), as follows:

$$
\begin{aligned}
\bar{\theta}_{\mathrm{i}} & =\sum_{i=1}^{n} w_{\mathrm{i}} \times \hat{\theta} \text { and } \\
S E(\bar{\theta}) & =\sum_{i=1}^{n} w_{\mathrm{i}} \times\left[\operatorname{var}\left(\hat{\theta}_{i_{i} /}\right)+\left(\hat{\theta}_{\mathrm{i}}-\bar{\theta}\right)^{2}\right]^{1 / 2},
\end{aligned}
$$

where $S E(\bar{\theta})=$ the standard error of the mean $\bar{\theta}$;

$\bar{\theta}=$ the parameter to be averaged; 

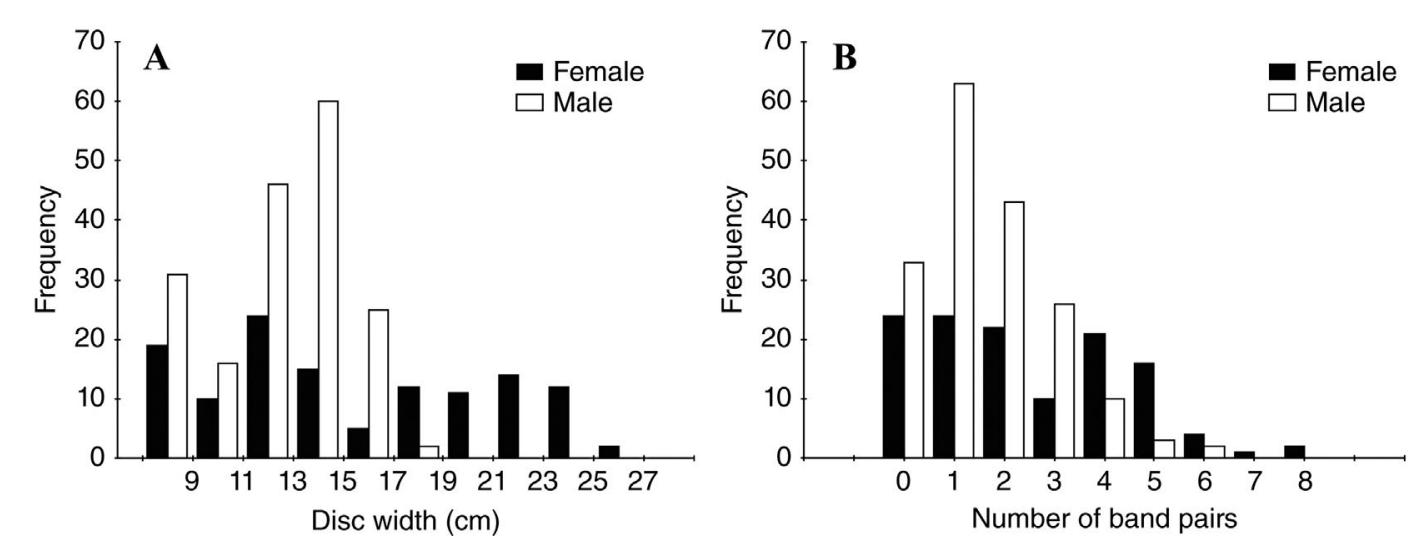

Figure 1

Frequency distribution of (A) sizes (disc width) and (B) ages (number of band pairs) for female and male Panamic stingrays (Urotrygon aspidura) collected in the central zone of the Pacific coast of Colombia in 2006-2009 and 2015 by small-scale, shallow-water shrimp fishing operations.

$$
\begin{aligned}
i & =\text { the model } ; \\
w_{\mathrm{i}}= & \text { the Akaike weight of model } i ; \\
\operatorname{var}\left(\hat{\theta}_{\mathrm{i} / \mathrm{i}}\right)= & \text { the variance of the estimated parameter for } \\
& \text { model } i ; \text { and } \\
\hat{\theta} & =\text { the estimated parameter for model } i .
\end{aligned}
$$

Finally, differences in growth curves between sexes for the selected models were tested by using a likelihood ratio test (Kimura, 1980; Haddon, 2001).

\section{Results}

A total of 309 specimens of the Panamic stingray (184 males and 125 females) were analyzed, and only 5 specimens were discarded for poor definition of band pairs and problems with reaching a consensus in reading. Female DW ranged from 7.1 to $26.5 \mathrm{~cm}$, and male DW ranged from 7.0 to $18.5 \mathrm{~cm}$, with most males measuring 11-15 cm DW (Fig. 1A). Females were significantly larger (15.6 cm DW [standard deviation [SD] 5.5, $n=124)$ than males (12.6 cm DW [SD 2.6], $n=180, Z=3.92, P<0.0001$ ).

Readings of vertebral sections had high reproducibility, with no systematic bias between readers ( $P=0.25$; Fig. 2 ), high percentage of agreement between readers $(87.4 \%$ with no differences in readings and $99.0 \%$ with differences of only 1 band pair), and relatively low error (APE $=4.06 \%$, $\mathrm{CV}=6.25 \%, n=309$ ). Females had a maximum of 8 band pairs, but most of them (56.5\%) had between 0 and 2 band pairs. Males had a maximum of 6 band pairs, and $91.7 \%$ of them had between 0 and 3 band pairs (Fig. 1B). From seasonally adjusted data, the maximum ages were 7.5 and 5.5 years for females and males, respectively.

The analysis of edge type did not show a completely clear pattern with respect to the monthly deposition of band pairs. This result could have been influenced by the low number of specimens collected during the first quarter of the year (Suppl. Table 2). However, it was possible to observe a trend that indicates annual accumulation, with the opaque band forming from the first months of the year until July and the translucent band forming approximately from August until February (Fig. 3A).

There were significant differences in MI among months (Kruskal-Wallis test: $H=24.06, P=0.008, n=141$ ). Monthly variations of the $\mathrm{MI}$ indicate that band pairs start to form the opaque band during the first months of the year, with higher mean values in October and November when the translucent band is formed (Fig. 3B). Despite the small sample size during February-May, these results indicate an annual periodicity in the formation of band pairs.

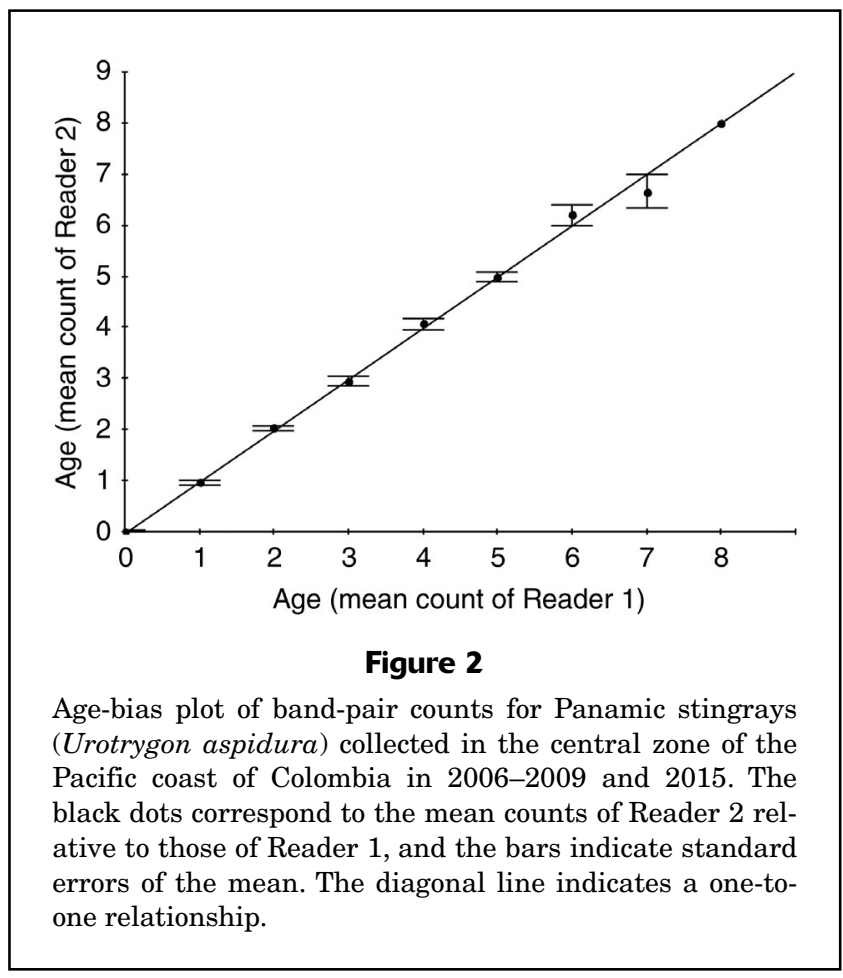



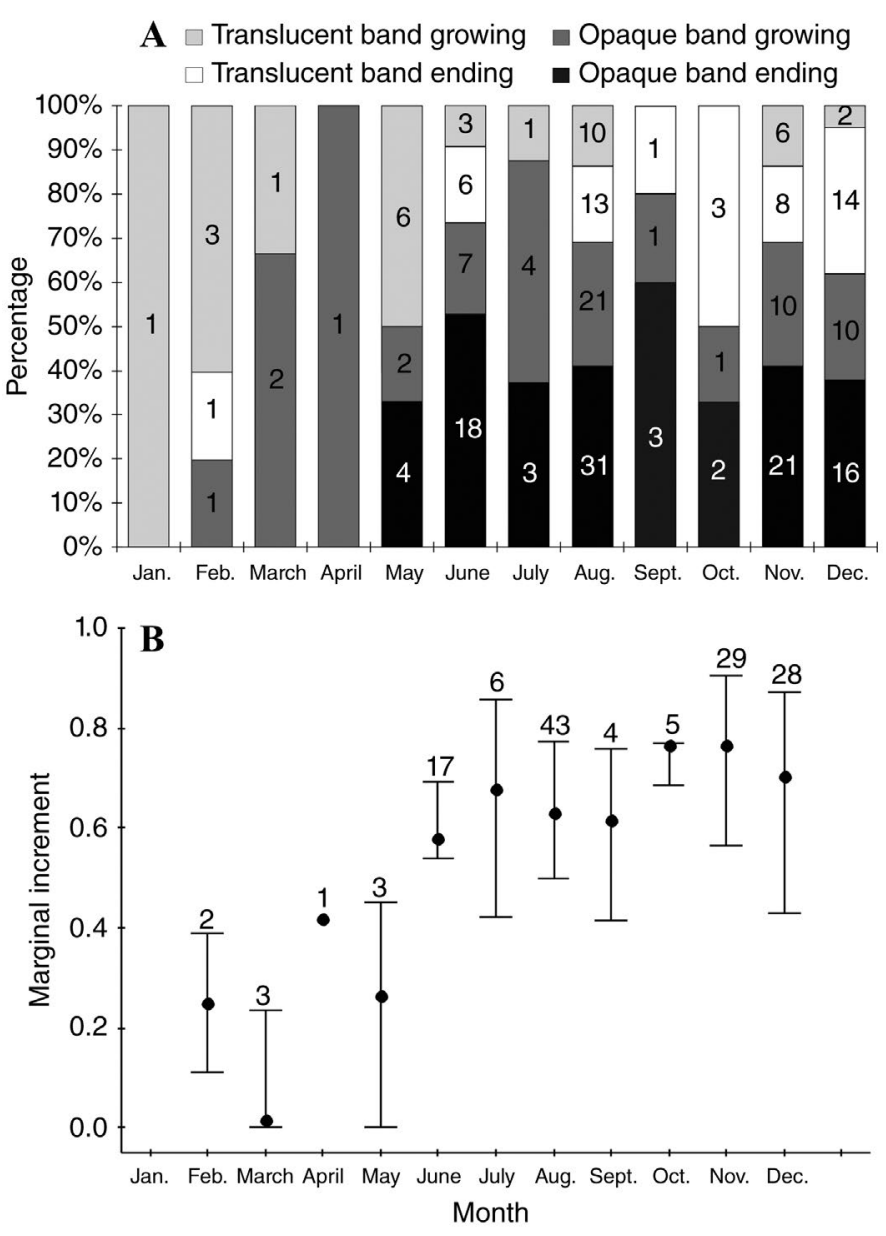

Figure 3

Monthly variation in the formation of vertebral band pairs of Panamic stingrays (Urotrygon aspidura) collected in the central zone of the Pacific coast of Colombia in 2006-2009 and 2015. (A) Percentage of Panamic stingrays (sample size $[n]=237$ ) that had 1 of 4 edge types: opaque band growing or ending and translucent band growing or ending. Numerals inside column sections indicate the number of vertebrae with that edge type. (B) Marginal increment index ( $n=141)$, with black dots corresponding to the median and the error bars indicating the 25th and 75th percentiles. Numerals above the top error bars indicate the sample size for each month.
Growth estimation analyses were more conclusive when seasonally adjusted age data were used, with both the 4and 5-parameter models (TPGM-4 and TPGM-5) for both sexes having the higher Akaike weight values (Tables 1 and 2). Parameters estimated from multi-model inference based on those TPGMs for both sexes are provided at the end of Tables 1 and 2 .

The TPGM-5 was chosen for both sexes on the basis of statistical $\left(\mathrm{AIC}_{\mathrm{i}}\right.$ ) and biological (known maximum $\mathrm{DW}, \mathrm{DW}$ at birth, and DW at maturity) fit (Tables 1 and 2, Fig. 4). The growth curves from the TPGM-5 were significantly different between sexes (likelihood ratio test: $\chi^{2}=115.6$, $\mathrm{df}=5, P<0.0001$ ), although the inflection point was similar between sexes (likelihood ratio test: $\chi^{2}=1.024$, $\mathrm{df}=1, P=0.312$; Tables 1 and 2; Fig. 4). Female Panamic stingrays had a larger asymptotic DW (likelihood ratio test: $\chi^{2}=748.1, \mathrm{df}=1, P<0.0001$ ) and a lower growth coefficient (likelihood ratio test: $\left.\chi^{2}=65.2, \mathrm{df}=1, P<0.0001\right)$ than male Panamic stingrays.

\section{Discussion}

Despite the significant increase in the number of age and growth studies in batoids, only 3 of the 16 American round ray species of the Urotrygonidae have been aged (Mejía-Falla et al., 2014; Guzmán-Castellanos, 2015; SantanderNeto, 2015). Our results agree with those of previous studies and demonstrate that the Panamic stingray is a fast-growing and short-lived species. This finding has considerable implications for the population assessment and management of this species.

The results from our study indicate that the vertebrae of Panamic stingrays, despite their small size, were adequate structures for evaluation and estimation of age for this species, with lower $\mathrm{APE}$ and $\mathrm{CV}$ values for readings than the averages of the age studies reported by Campana (2001) (APE $<5.5 \%$ and $\mathrm{CV}<7.6 \%$ ) and those observed in readings for species of the Urotrygonidae (average $\mathrm{APE}=4.24 \%$; Mejía-Falla et al., 2014; GuzmánCastellanos, 2015; Santander-Neto, 2015).

The region of the vertebral column chosen for extraction of the centra sample and the centra size have effects on the counting of shark growth band pairs, with the largest ones showing more pairs of bands (Natanson et al., 2018). In this study, we used the largest centra of each specimen from the abdominal region, to maintain homogeneity in samples and reduce those effects. This issue can be addressed by alternative techniques, such as bomb radiocarbon dating or chemical fluorochrome marking, but these techniques are costly and are not easily accessible.

Despite the limited sample size in the first months of the year, the results of MI analysis indicate that band-pair formation tends to be annual in Panamic stingrays, with constant MI growth from the beginning of the year until October and November. Although MI analysis has been considered a validation method (Campana, 2001), in this study, we used it as a method for verification of the periodicity in band deposition (Cailliet and Goldman, 2004). This annual band-pair deposition based on MI has been described for numerous species from the Urolophidae and Urotrygonidae (White et al., 2001; White et al., 2002; White and Potter, 2005; Mejía-Falla et al., 2014; Guzmán-Castellanos, 2015; Santander-Neto, 2015). Yearly periodicity of band-pair formation has been 


\section{Table 1}

Parameters and statistical criteria for the von Bertalanffy growth model (VBGM), two-phase growth model (TPGM), Gompertz growth model (GGM), and logistic growth model (LGM) used to describe the growth of female Panamic stingrays (Urotrygon aspidura) (sample size $[n]=124$ ) collected in the central zone of the Pacific coast of Colombia in 2006-2009 and 2015. Two data sets are presented; the adjusted data set considers the months with peaks of reproduction and the unadjusted data set does not consider them. The parameters and criteria are asymptotic disc width $\left(D W_{\infty}\right.$, in centimeters), birth size ( $D W_{0}$, fixed to $7.5 \mathrm{~cm}$ for models with 2 and 4 parameters), annual growth rate $(k)$, theoretical age at zero $\left(t_{0}\right)$, age at transition between 2 phases or inflection point $\left(t_{\mathrm{h}}\right)$, maximum difference in DW at age between the VBGM and TPGM at the $t_{\mathrm{h}}(h)$, Akaike information criterion $\left(\mathrm{AIC}_{\mathrm{i}}\right)$, difference in $\mathrm{AIC}_{\mathrm{i}}$ between models $\left(\Delta_{\mathrm{i}}\right)$, and Akaike weight $\left(w_{\mathrm{i}}\right)$. Weighted averages from the TPGM are given with standard errors of the mean (SEs). Numerals after the model abbreviation indicate the number of parameters used in that model. Dashes indicate that data were not available because variables were not included in a model.

\begin{tabular}{lcccccrrrr}
\hline Model & $D W_{\infty}$ & $k$ & $t_{0}$ & $t_{\mathrm{h}}$ & $h$ & $D W_{0}$ & $\mathrm{AIC}_{\mathrm{i}}$ & $\Delta_{\mathrm{i}}$ & $w_{\mathrm{i}}$ \\
\hline Unadjusted data & & & & & & & & & \\
VBGM-3 & 29.32 & 0.24 & -1.80 & - & - & 10.28 & 556.61 & 1.65 & 0.17 \\
VBGM-2 & 25.46 & 0.42 & - & - & - & 7.50 & 615.64 & 60.68 & 0.00 \\
GGM-3 & 26.82 & 0.40 & -0.12 & - & - & 10.33 & 556.02 & 1.06 & 0.22 \\
GGM-2 & 23.91 & 0.69 & - & - & - & 7.50 & 618.25 & 63.29 & 0.00 \\
LGM-3 & 25.60 & 0.57 & 0.67 & - & - & 10.38 & 555.95 & 0.99 & 0.23 \\
LGM-2 & 20.40 & 0.79 & - & - & - & 12.50 & 628.75 & 73.79 & 0.00 \\
TPGM-5 & 24.93 & 0.47 & -1.21 & 1.93 & 0.31 & 10.31 & 554.96 & 0.00 & 0.38 \\
TPGM-4 & 24.03 & 0.68 & - & 2.14 & 0.46 & 7.50 & 614.67 & 59.71 & 0.00 \\
Adjusted data & & & & & & & & \\
VBGM-3 & 29.60 & 0.22 & -1.53 & - & - & 8.63 & 536.69 & 6.84 & 0.02 \\
VBGM-2 & 26.64 & 0.31 & - & - & - & 7.50 & 542.49 & 12.65 & 0.00 \\
GGM-3 & 26.89 & 0.38 & 0.26 & - & - & 8.91 & 537.30 & 7.45 & 0.01 \\
GGM-2 & 24.51 & 0.54 & - & - & - & 7.50 & 549.79 & 19.94 & 0.00 \\
LGM-3 & 25.62 & 0.55 & 1.08 & - & - & 9.13 & 538.23 & 8.38 & 0.01 \\
LGM-2 & 20.07 & 0.60 & - & - & - & 12.34 & 652.41 & 122.56 & 0.00 \\
TPGM-5 & 24.71 & 0.47 & -0.91 & 2.32 & 0.36 & 8.18 & 530.01 & 0.16 & 0.46 \\
TPGM-4 & 24.02 & 0.57 & - & 2.24 & 0.53 & 7.50 & 529.85 & 0.00 & 0.50 \\
Weighted & & & & & & & & - & - \\
average from & 24.35 & 0.52 & - & 2.28 & 0.45 & - & & -
\end{tabular}

validated through the use of tetracycline for the round stingray (Urobatis halleri), white-blotched river stingray (Potamotrygon leopoldi), and little skate (Leucoraja erinacea) (Hale and Lowe, 2008; Cicia et al., 2009; Charvet et al., 2018). This validation does not imply a generalized pattern for batoids, but it does allow inference that yearly periodicity occurs regularly in this group, regardless of the taxonomic classification, habitats, or latitudinal distributions of the species.

Although band pairs may begin to form during the first trimester of the year, starting with the opaque band, the reduced sample size during those months limited our capacity to determine with precision in which month this process starts. Several studies have also reported on the difficulty in validating band formation in sharks and rays (O'Shea et al., 2013; Cailliet, 2015); therefore, it has been assumed that 1 pair is formed each year. Carlson et al. (1999) and Lessa et al. (2006) attribute this difficulty to a bias of MI values and inconclusive analyses due to long sampling periods (several years) during which births occur over a long time span and organisms from the same cohort are born at different times of the year. Such multiple births could be the case for the Panamic stingray, as the reproductive information available for this species (P.Mejía-Falla et al., unpubl.data) and for a sympatric species, the thorny stingray (Urotrygon rogersi) (Mejía-Falla et al., 2014), indicates that there is continuous reproduction throughout the year with $2-3$ reproductive events per year.

In female and male Panamic stingrays, differences in age and growth parameters were observed. The maximum estimated female age was 7.5 years, whereas the maximum estimated male age was 5.5 years. Similar values have also been recorded for other species of this family, such as the smalleyed round stingray ( $U$. microphthalmum) with 8.5 years for females of and 5.5 years for males (Santander-Neto, 2015) and the thorny stingray with 8 years for females and 6 years for males (Mejía-Falla et al., 2014). In contrast, the blotched stingray (U. chilensis) has 


\section{Table 2}

Parameters and statistical criteria for the von Bertalanffy growth model (VBGM), two-phase growth model (TPGM), Gompertz growth model (GGM), and logistic growth model (LGM) used to describe the growth of male Panamic stingrays (Urotrygon aspidura) (sample size $[n]=180$ ) collected in the central zone of the Pacific coast of Colombia in 2006-2009 and 2015. Two data sets are presented; the adjusted data set considers the months with peaks of reproduction. The parameters and criteria are the asymptotic disc width $\left(D W_{\infty}\right.$, in centimeters), birth size $\left(D W_{0}\right.$, fixed to $7.5 \mathrm{~cm}$ for models with 2 and 4 parameters), annual growth rate $(k)$, age at transition between 2 phases or inflection point $\left(t_{\mathrm{h}}\right)$, maximum difference in DW at age between the VBGM and TPGM at the $t_{\mathrm{h}}(h)$, Akaike information criterion ( $\mathrm{AIC}_{\mathrm{i}}$ ), difference in $\mathrm{AIC}_{\mathrm{i}}$ between models $\left(\Delta_{\mathrm{i}}\right)$, and Akaike weight $\left(w_{\mathrm{i}}\right)$. Weighted averages from the TPGM are given with standard errors of the mean (SEs). Numerals after the model abbreviation indicate the number of parameters used in that model. Dashes indicate that data were not available because variables were not included in a model.

\begin{tabular}{lcccccrrrr}
\hline Model & $D W_{\infty}$ & $k$ & $t_{0}$ & $t_{\mathrm{h}}$ & $h$ & $D W_{0}$ & $\mathrm{AIC}_{\mathrm{i}}$ & $\Delta_{\mathrm{i}}$ & $w_{\mathrm{i}}$ \\
Unadjusted data & & & & & & & & & \\
VBGM-3 & 15.99 & 0.79 & -1.47 & - & - & 10.97 & 736.08 & 0.00 & 0.27 \\
VBGM-2 & 15.31 & 1.65 & - & - & - & 7.50 & 924.74 & 188.65 & 0.00 \\
GGM-3 & 15.84 & 0.93 & -1.08 & - & - & 10.97 & 736.42 & 0.34 & 0.22 \\
GGM-2 & 15.22 & 2.00 & - & - & - & 7.50 & 924.88 & 188.79 & 0.00 \\
LGM-3 & 15.72 & 1.08 & -0.77 & - & - & 10.97 & 736.75 & 0.67 & 0.19 \\
LGM-2 & 17.05 & 0.72 & - & - & - & 10.93 & 737.38 & 1.30 & 0.14 \\
TPGM-5 & 17.11 & 0.81 & -1.33 & 2.60 & 0.40 & 10.95 & 736.83 & 0.75 & 0.18 \\
TPGM-4 & 16.81 & 1.45 & - & 2.56 & 0.68 & 7.50 & 927.01 & 190.92 & 0.00 \\
Adjusted data & & & & & & & & \\
VBGM-3 & 15.08 & 1.34 & -0.63 & - & - & 8.59 & 640.61 & 4.10 & 0.08 \\
VBGM-2 & 14.85 & 1.76 & - & - & - & 7.50 & 646.70 & 10.19 & 0.00 \\
GGM-3 & 14.82 & 1.90 & -0.28 & - & - & 8.20 & 644.78 & 8.27 & 0.01 \\
GGM-2 & 14.71 & 2.26 & - & - & - & 7.50 & 647.85 & 11.35 & 0.00 \\
LGM-3 & 14.70 & 2.38 & -0.10 & - & - & 8.17 & 646.05 & 9.55 & 0.01 \\
LGM-2 & 14.65 & 1.52 & - & - & - & 9.84 & 674.94 & 38.43 & 0.00 \\
TPGM-5 & 15.96 & 1.63 & -0.48 & 2.22 & 0.54 & 8.07 & 636.51 & 0.00 & 0.64 \\
TPGM-4 & 15.94 & 1.81 & - & 2.16 & 0.67 & 7.50 & 638.30 & 1.80 & 0.26 \\
Weighted & & & & & & & & - & -
\end{tabular}

older ages of 14 years for females and 12 years for males (Guzmán-Castellanos, 2015). The Panamic stingray can be considered a short-lived species (<8 years), similar to other species belonging to Urotrygonidae (Hale and Lowe, 2008; Mejía-Falla et al., 2014; Santander-Neto, 2015), whereas in other ray families, such as Dasyatidae and Rajidae, maximum ages can exceed 17 years (Francis et al., 2001; Licandeo et al., 2006; Smith et al., 2007; Aversa et al., 2011; Başusta and Sulikowski, 2012; O'Shea et al., 2013).

Traditionally, the most used model to describe elasmobranch growth (Cailliet et al., 2006) has been the VBGM; however, numerous studies indicate that other models can be better adjusted (Araya and Cubillos, 2006; Smart et al., 2016). The Gompertz growth model has been used with batoid species (Neer and Cailliet, 2001; Neer and Thompson, 2005; Matta and Gunderson, 2007; Ainsley et al., 2011), and the TPGM, which incorporates changes in growth rates during the lives of organisms, usually has been related with changes in energy investment in reproductive processes (Araya and Cubillos, 2006; Aversa et al., 2011).

Differences in the age parameters obtained between the adjusted and the unadjusted age data, the former being more similar to the biological data, demonstrate the importance of considering the reproductive and size characteristics of each species, as well as the multi-model approach, to obtain more reliable growth parameters (Harry et al., 2010; Mejía-Falla et al., 2014). However, most age studies do not include adjustment based on the reproductive cycle, ignoring the potential effects that lack of adjustment could have on the demographic analyses and, therefore, on the fishery management of these cartilaginous fish species (Cailliet, 2015).

It has been suggested that the use of different models (or a multi-model approach) in growth studies allows researchers to select the model that is best adjusted to the data (Katsanevakis, 2006; Smart et al., 2016). For demographic modeling purposes, of the 8 models applied to describe the DW-age relationship in the Panamic stingray, 


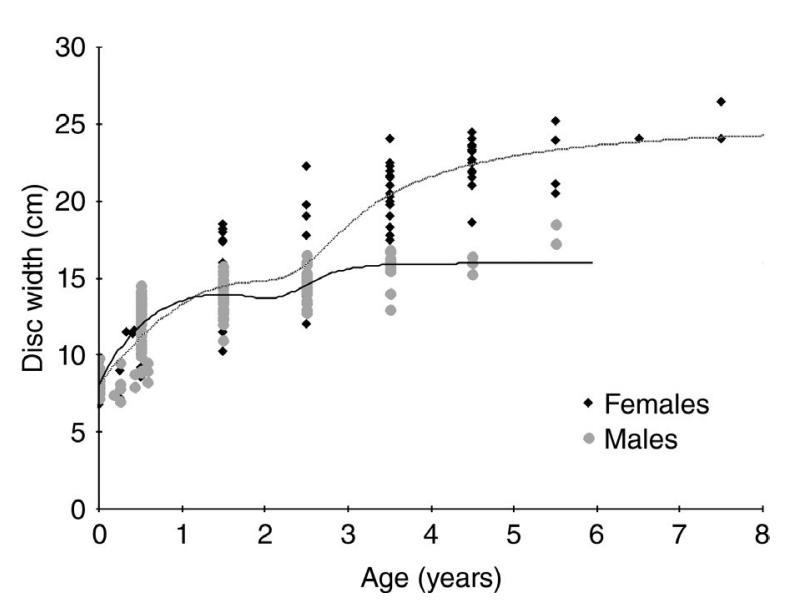

Figure 4

Two-phase growth model with 5 parameters that describes the growth of female (black diamonds, dotted line) and male (gray dots, solid line) Panamic stingrays (Urotrygon aspidura) collected in the central zone of the Pacific coast of Colombia in 2006-2009 and 2015. Adjusted data for age and disc width were used, meaning that data take into account the months with peaks of reproduction.

the growth parameters obtained from the TPGM-5 were considered best for describing the growth of this species. Similarly, TPGM was the best fitted to data for female blotched stingrays (Guzmán-Castellanos, 2015) and to data for female thorny stingrays (Mejía-Falla et al., 2014), making it the most appropriate model in the 3 age studies carried out to date for the genus Urotrygon.

The TPGM divides growth in 2 phases that could be related to changes in habitat, feeding habits, or the energetic investment of species (Aversa et al., 2011). The inflection point of females in this model occurred at 2.3 years and coincided with the size at first maturity estimated for the Panamic stingray. This size at maturity occurred at $25 \mathrm{~cm}$ TL and corresponds to a DW between 13.8 and $15.0 \mathrm{~cm}$ in our study (P. Mejía-Falla, unpubl. data). This change in growth rates (and their relationship with size at first maturity) has been associated with a higher energy investment in the development of reproductive organs, coinciding in some species with the change from juvenile to adult (Carlson and Baremore, 2005; Braccini et al., 2007; Aversa et al., 2011). As a consequence, the trajectory in the growth rate allows us to distinguish between before and after maturity (Araya and Cubillos, 2006), with maturation starting before reproduction (Aversa et al., 2011) and possibly reflected in a lower investment of energy in growth (Mejía-Falla et al., 2014).

Missing the smallest and largest individuals in a sample can affect growth models and produce biased growth parameters (Haddon, 2001; Pilling et al., 2002; Smart et al., 2015; D'Alberto et al., 2017). The variables were sensitive to the low number of older age classes for both sexes and, for males, to the influence that the predominance of
DW of $12-15 \mathrm{~cm}$ can have on data. This data sensitivity ensured that growth curves did not reach an asymptote resulting in underestimation of $D W_{\infty}$ (Fisher et al., 2013) and led to $D W_{\infty}$ estimates of $24.71 \mathrm{~cm}$ for females and $15.96 \mathrm{~cm}$ for males. The wide range in $D W_{0}$ could have been affected by a prolonged birthing period (Lessa et al., 2006) in the TPGMs for both sexes. Additionally, the low number of samples for certain size and age classes in our study may have contributed to the variability in $k$.

Among elasmobranchs, females reach greater asymptotic sizes and have lower growth rates than males (e.g., Ismen, 2003; Skomal and Natanson, 2003; Başusta et al., 2008; Kume et al., 2008). These differences in growth between sexes was observed for the Panamic stingray, with females reaching a $D W_{\infty}$ of $24.71 \mathrm{~cm}$ and a $k$ of $0.47 \mathrm{~cm} /$ year and males reaching a $D W_{\infty}$ of $15.96 \mathrm{~cm}$ and a $k$ of $1.63 \mathrm{~cm} /$ year. Such differences between sexes have usually been attributed to males reaching maturity earlier than females. Females would have the evolutionary advantage of increasing their size to increase fecundity or to have the capacity of sheltering more embryos and reaching maximum capacity (Aversa et al., 2011; Klimley, 2013).

Differences in growth between sexes have been found in other species of the Urotrygonidae and Urolophidae, such as the thorny stingray, smalleyed round stingray, round stingray, lobed stingaree (Urolophus lobatus), sparsely-spotted stingaree (U. paucimaculatus), masked stingaree (Trygonoptera personata), and western shovelnose stingaree (T. mucosa) (White et al., 2001; White et al., 2002; White and Potter, 2005; Hale and Lowe, 2008; MejíaFalla et al., 2014; Guzmán-Castellanos, 2015; SantanderNeto 2015). Compared with those species, the Panamic stingray has a higher growth rate, the highest reported for an elasmobranch so far. This species provides more evidence for the fact that smaller organisms grow faster and have a shorter lifespan than larger organisms (White and Sommerville, 2010; Aversa et al., 2011).

Although traditionally elasmobranchs have been described as $\mathrm{K}$ strategists, and they are therefore very vulnerable to fisheries, the results of recent studies give evidence that this pattern is not a general one in this group and that some species have life history traits that make them more productive and resistant to fisheries (Simpfendorfer, 1993; Cailliet et al., 2005; Mejía-Falla et al., 2014; White et al., 2014). This pattern was found for the Panamic stingray, a small-sized species with a short life and fast growth, characteristics that are similar to those found in its sympatric species, the thorny stingray (Mejía-Falla et al., 2014).

These life history characteristics have been advantageous for these species, allowing them to endure years of continuous fishing pressure (Rueda et al., 2006). Therefore, these characteristics make them 2 of the most abundant elasmobranch species in our study area, unlike other elasmobranchs, such as the Pacific smalltail shark (Carcharhinus cerdale), scalloped hammerhead (Sphyrna lewini), scoophead (S. media), sicklefin smoothhound (Mustelus lunulatus), and longtail stingray (Hypanus longus), among others (Navia and Mejía-Falla, 2016). Despite 
its abundance, analyses of the reproductive biology and demography of the Panamic stingray are necessary to define its real vulnerability to fisheries activities.

\section{Acknowledgments}

Funding for this study was provided by Colciencias-Colombia (RC 156-2010), Padi Foundation, and Iniciativa de Especies Amenazadas. We thank H. Paredes, F. Cuero, and SQUALUS staff for support with field work. The senior author was funded by scholarships from the Consejo Nacional de Ciencia y Tecnología (Mexico) and Instituto Politécnico Nacional (IPN) for studies toward her master's degree. C. Quiñonez and V. Cruz were supported by IPN programs, Estímulos al Desempeño de los Investigadores and Comisión de Operación y Fomento de Actividades Académicas.

\section{Literature cited}

Ainsley, S. M., D. A. Ebert, and G. M. Cailliet.

2011. Age, growth, and maturity of the whitebrow skate, Bathyraja minispinosa, from the eastern Bering Sea. ICES J. Mar. Sci. 68:1426-1434. Crossref

Akaike, $\mathrm{H}$.

1973. Information theory as an extension of the maximum likelihood principle. In Second international symposium on information theory; Tsahkadsor, Armenia, 2-8 September 1971 (B. N. Petrov and F. Csáki, eds.), p. 267-281. Akadémiai Kiadó, Budapest, Hungary.

Amezcua, F., J. Madrid-Vera, and H. Aguirre-Villaseñor.

2006. Efecto de la pesca artesanal de camarón sobre la ictiofauna en el sistema lagunar de Santa María la Reforma, suroeste del Golfo de California. Cienc. Mar. 32:97-109. Crossref

Araya, M., and L. A. Cubillos.

2006. Evidence of two-phase growth in elasmobranchs. Environ. Biol. Fish. 77:293-300. Crossref

Aversa, M. I., S. L. Dans, N. A. García, and E. A. Crespo.

2011. Growth models fitted to Dipturus chilensis length-atage data support a two phase growth. Rev. Chil. Hist. Nat. 84:33-49. Crossref

Babel, J. S.

1967. Reproduction, life history, and ecology of the round stingray, Urolophus halleri Cooper. Calif. Dep. Fish Game, Fish Bull. 137, 104 p.

Başusta, N., and J. A. Sulikowski.

2012. The oldest estimated age for roughtail stingray [Dasyatis centroura (Mitchill, 1815)] from the Mediterranean Sea. J. Appl. Ichthyol. 28:641-642. Crossref

Başusta, N., S. A. Demirhan, E. Çiçek, A. Başusta, and T. Kuleli. 2008. Age and growth of the common guitarfish, Rhinobatos rhinobatos, in Iskenderun Bay (north-eastern Mediterranean, Turkey). J. Mar. Biol. Assoc. U.K. 88:837-842. Crossref

Beamish, R. J., and D. A. Fournier.

1981. A method for comparing the precision of a set of age determinations. Can. J. Fish. Aquat. Sci. 38:982-983. Crossref

Braccini, J. M., B. M. Gillanders, T. I. Walker, and J. Tovar-Avila. 2007. Comparison of deterministic growth models fitted to length-at-age data of the piked spurdog (Squalus megalops) in south-eastern Australia. Mar. Freshw. Res. 58: 24-33. Crossref

Burnham, K. P., and D. R. Anderson.

2002. Model selection and multimodel inference: a practical information-theoretic approach, $2^{\text {nd }}$ ed., 488 p. Springer Science, New York.

Cailliet, G. M.

2015. Perspectives on elasmobranch life history studies: a focus on age validation and relevance to fishery management. J. Fish. Biol. 87:1271-1292. Crossref

Cailliet, G. M., and K. J. Goldman.

2004. Age determination and validation in chondrichthyan fishes. In Biology of sharks and their relatives (J. C. Carrier, J. A. Musick, M. R. Heithaus, eds.), p. 399-447. CRC Press, Boca Raton, FL.

Cailliet, G. M., J. A. Musick, C. A. Simpfendorfer, and J. D. Stevens.

2005. Ecology and life history characteristics of chondrichthyan fish. In Sharks, rays and chimaeras: the status of the chondrichthyan fishes. Status survey (S. L. Fowler, R. D. Cavanagh, M. Camhi, G. H. Burgess, G. M. Cailliet, S. V. Fordham, C. A. Simpfendorfer, and J. A. Musick, eds.), p. 12-18. IUCN, Gland, Switzerland.

Cailliet, G. M., W. D. Smith, H. F. Mollet, and K. J. Goldman.

2006. Age and growth studies of chondrichthyan fishes: the need for consistency in terminology, verification, validation, and growth function fitting. Environ. Biol. Fish. 77:211-228. Crossref.

Campana, S. E.

2001. Accuracy, precision and quality control in age determination, including a review of the use and abuse of age validation methods. J. Fish Biol. 59:197-242. Crossref

Campana, S. E., M. C. Annand, and J. I. McMillan.

1995. Graphical and statistical methods for determining the consistency of age determinations. Trans. Am. Fish. Soc. 124:131-138. Crossref

Carlson, J. K., and I. E. Baremore.

2005. Growth dynamics of the spinner shark (Carcharhinus brevipinna) off the United States southeast and Gulf of Mexico coasts: a comparison of methods. Fish. Bull. 103:280-291.

Carlson, J. K., E. Cortés, and A. G. Johnson.

1999. Age and growth of the blacknose shark, Carcharhinus acronotus, in the eastern Gulf of Mexico. Copeia 1999:684691. Crossref

Charvet, P., F. M. Santana, K. L. De Lima, and R. Lessa.

2018. Age and growth of the endemic Xingu River stingray Potamotrygon leopoldi validated using fluorescent dyes. J. Fish. Biol. 92:1985-1999. Crossref

Cicia, A. M., W. B. Driggers III, G. W. Ingram Jr., J. Kneebone, P. C. W. Tsang, D. M. Koester, and J. A. Sulikowski.

2009. Size and age estimates at sexual maturity for the little skate Leucoraja erinacea from the western Gulf of Maine, USA. J. Fish. Biol. 75:1648-1666. Crossref

Clarke, T. M., M. Espinoza, R. Ahrens, and I. S. Wehrtmann.

2016. Elasmobranch bycatch associated with the shrimp trawl fishery off the Pacific coast of Costa Rica, Central America. Fish. Bull. 114:1-17. Crossref

Cortés, E.

2000. Life history patterns and correlations in sharks. Rev. Fish. Sci. 8:299-344. Crossref

D’Alberto, B. M., A. Chin, J. J. Smart, L. Baje, W. T. White, and C. A. Simpfendorfer.

2017. Age, growth and maturity of oceanic whitetip shark (Carcharhinus longimanus) from Papua New Guinea. Mar. Freshw. Res. 68:1118-1129. Crossref 
Fisher, R. A., G. C. Call, and R. D. Grubbs.

2013. Age, growth, and reproductive biology of cownose rays in Chesapeake Bay. Mar. Coast. Fish. 5:224-235. Crossref

Francis, M. P., C. Ó. Maolagáin, and D. Stevens.

2001. Age, growth, and sexual maturity of two New Zealand endemic skates, Dipturus nasutus and D. innominatus. N. Z. J. Mar. Freshw. Res. 35:831-842. Crossref

Frisk, M. G.

2010. Life history strategies of batoids. In Sharks and their relatives II: biodiversity, adaptive physiology, and conservation (J. C. Carrier, J. A. Musick, and M. R. Heithaus, eds.), p. 283-316. CRC Press, Boca Raton, FL.

González-Isáis, M., and H. M. Montes-Domínguez.

2016. Compared morphology of the cephalic musculature in five species of genus Urotrygon (Chondrichthyes: Urolophidae). Int. J. Morphol. 34:7-12. Crossref

Guzmán-Castellanos, A. B.

2015. Historia de vida de la raya chilena Urotrygon chilensis (Günther, 1872) en el sureste del Pacífico mexicano. Ph.D. diss., 133 p. Cent. Invest. Biol. Noroeste, La Paz, Mexico. [Available from website.]

Haddon, M.

2001. Modelling and quantitative methods in fisheries, $2^{\text {nd }}$ ed., 465 p. CRC Press, Boca Raton, FL.

Hale, L. F., and C. G. Lowe.

2008. Age and growth of the round stingray Urobatis halleri at Seal Beach, California. J. Fish Biol. 73:510-523. Crossref

Harry, A. V., C. A. Simpfendorfer, and A. J. Tobin.

2010. Improving age, growth, and maturity estimates for aseasonally reproducing chondrichthyans. Fish. Res. 106: 393-403. Crossref

Hayashi, Y.

1976. Studies on the growth of the red tilefish in the East China Sea-II: estimation of age and growth from otolith-reading. Bull. Jpn. Soc. Sci. Fish. 42:1243-1249. Crossref

Hoenig, J. M., M. J. Morgan, and C. A. Brown.

1995. Analysing differences between two age determination methods by tests of symmetry. Can. J. Fish. Aquat. Sci. 52:364-368. Crossref

Ismen, $\mathrm{A}$.

2003. Age, growth, reproduction and food of common stingray (Dasyatis pastinaca L., 1758) in Iskenderun Bay, the eastern Mediterranean. Fish. Res. 60:169-176. Crossref

Licandeo, R. R., J. G. Lamilla, P. G. Rubilar, and R. M. Vega.

2006. Age, growth, and sexual maturity of the yellownose skate Dipturus chilensis in the south eastern Pacific. J. Fish Biol. 68:488-506. Crossref

Katsanevakis, S.

2006. Modelling fish growth: model selection, multi-model inference and model selection uncertainty. Fish. Res. 81:229-235. Crossref

Kimura, D. K.

1980. Likelihood methods for the von Bertalanffy growth curve. Fish. Bull. 77:765-774.

Klimley, A. P.

2013. Diet and growth. In The biology of sharks and rays, p. 339-372. Univ. Chicago Press, Chicago, IL.

Kume, G., K. A. Furumitsu, and A. Yamaguchi.

2008. Age, growth and age at sexual maturity of fan ray Platyrhina sinensis (Batoidea: Platyrhinidae) in Ariake Bay, Japan. Fish. Sci. 74:736-742. Crossref

Lessa, R., F. M. Santana, and P. Duarte-Neto.

2006. A critical appraisal of marginal increment analysis for assessing temporal periodicity in band formation among tropical sharks. Environ. Biol. Fish. 77:309-315. Crossref
Matta, M. E., and D. R. Gunderson.

2007. Age, growth, maturity, and mortality of the Alaska skate, Bathyraja parmifera, in the eastern Bering Sea. Environ. Biol. Fish. 80:309-323. Crossref

Mejía-Falla, P. A.

2012. Historia de vida y demografía de la raya espinosa Urotrygon rogersi en dos áreas con distintos niveles de presión pesquera. Ph.D. diss., 132 p. Univ. Valle, Cali, Colombia.

Mejía-Falla, P. A., E. Cortés, A. F. Navia, and F. A. Zapata.

2014. Age and growth of the round stingray Urotrygon rogersi, a particularly fast-growing and short-lived elasmobranch. PLoS ONE 9(4):e96077. Crossref

Montes-Domínguez, H. M., and M. González-Isáis.

2017. Skeleton anatomy of five species of genus Urotrygon (Chondrichthyes: Urotrygonidae). Int. J. Morphol. 35:831839. Crossref

Morales-Azpeitia, R., J. López-Martínez, C. H. Rábago-Quiroz, M. O. Nevárez-Martínez, and E. Herrera-Valdivia.

2013. Growth and mortality rates of Pseudupeneus grandisquamis and Urobatis halleri bycatch species in the shrimp fishery. Hidrobiológica 23:386-393.

Natanson, L. J., G. B. Skomal, S. L. Hoffmann, M. E. Porter, K. J. Goldman, and D. Serra.

2018. Age and growth of sharks: do vertebral band pairs record age? Mar. Freshw. Res. 69:1440-1452. Crossref

Navarro-González, J. A., J. Bohórquez-Herrera, A. F. Navia, and

V. H. Cruz-Escalona.

2012. Diet composition of batoids on the continental shelf off Nayarit and Sinaloa, Mexico. Cienc. Mar. 38:347-362. Crossref

Navarro-González, J. A., U. Rubio-Rodríguez, P. A. Mejía-Falla, and V. H. Cruz-Escalona.

2018. Morphological description of adult mouthparts of Urotrygon nana and $U$. rogersi (Urotrygonidae): interspecific and intraspecific differences. Hidrobiológica 28:219-222. Crossref

Navia, A. F., and P. A. Mejía-Falla.

2016. Fishing effects on elasmobranchs from the Pacific Coast of Colombia. Univ. Sci. 21:9-22. Crossref

Navia, A. F., P. A. Mejía-Falla, L. A. Zapata, S. Bessudo, G. Soler, and E. Rubio.

2009. Estado del conocimiento de tiburones y rayas del Pacífico colombiano. In Avances en el conocimiento de tiburones, rayas y quimeras de Colombia (V. Puentes, A. F. Navia, P. A. Mejía-Falla, J. P. Caldas, M. C. Diazgranados, and L. A. Zapata-Padilla, eds.), p. 131-194. Fundación SQUALUS, Cali, Colombia.

Neer, J. A., and G. M. Cailliet.

2001. Aspects of the life history of the Pacific electric ray, Torpedo californica (Ayres). Copeia 2001:842-847.

Neer, J. A., and B. A. Thompson.

2005. Life history of the cownose ray, Rhinoptera bonasus, in the northern Gulf of Mexico, with comments on geographic variability in life history traits. Environ. Biol. Fish. 73:321-331. Crossref

O'Shea, O. R., M. Braccini, R. McAuley, C. W. Speed, and M. G. Meekan.

2013. Growth of tropical dasyatid rays estimated using a multi-analytical approach. PLoS ONE 8(10):e77194. Crossref

Pilling, G. M., G. P. Kirkwood, and S. G. Walker.

2002. An improved method for estimating individual growth variability in fish, and the correlation between von Bertalanffy growth parameters. Can. J. Fish. Aquat. Sci. 59:424432. Crossref 
Ricker, W. E.

1979. Growth rates and models. In Fish physiology, vol. 8 (W. S. Hoar, D. J. Randall, and J. R. Brett, eds.), p. 677-743. Academic Press, New York.

Rico-Mejía, F., and M. Rueda.

2007. Evaluación experimental bioeconómica de cambios en la tecnología de captura de camarón con redes de arrastre en aguas someras del Pacífico colombiano. Bol. Invest. Mar. Cost. 36:79-109.

Robertson, D. R., and G. R. Allen.

2015. Shorefishes of the Tropical Eastern Pacific: online information system, vers. 2.0. Smithsonian Tropical Research Institute, Balboa, Panama. [Available from website, accessed May 2018.]

Rueda, M., J. A. Angulo S., N. Madrid, F. Rico, and A. Girón.

2006. La pesca industrial de arrastre de camarón en aguas someras del Pacífico colombiano: su evolución, problemática y perspectivas hacia una pesca responsable, $60 \mathrm{p}$. INVEMAR, Santa Marta, Colombia.

Santander-Neto, J.

2015. Dinâmica populacional da raia Urotrygon microphthalmum Delsman, 1941 no nordeste do Brasil. Ph.D. diss., 135 p. Univ. Fed. Pernambuco, Recife, Brazil. [Available from website.]

Simpfendorfer, C. A.

1993. Age and growth of the Australian sharpnose shark, Rhizoprionodon taylori, from north Queensland, Australia. Environ. Biol. Fish. 36:233-241. Crossref

Skomal, G. B., and L. J. Natanson.

2003. Age and growth of the blue shark (Prionace glauca) in the North Atlantic Ocean. Fish. Bull. 101:627-639.

Smart, J. J., A. V. Harry, A. J. Tobin, and C. A. Simpfendorfer. 2013. Overcoming the constraints of low sample sizes to produce age and growth data for rare or threatened sharks. Aquat. Conserv. 23:124-134. Crossref

Smart, J. J., A. Chin, A. J. Tobin, C. A. Simpfendorfer, and W. T. White.

2015. Age and growth of the common blacktip shark Carcharhinus limbatus from Indonesia, incorporating an improved approach to comparing regional population growth rates. Afr. J. Mar. Sci. 37:177-188. Crossref

Smart, J. J., A. Chin, A. J. Tobin, and C. A. Simpfendorfer. 2016. Multimodel approaches in shark and ray growth studies: strengths, weaknesses and the future. Fish Fish. 17:955-971. Crossref
Smith, W. D., G. M. Cailliet, and E. M. Melendez.

2007. Maturity and growth characteristics of a commercially exploited stingray, Dasyatis dipterura. Mar. Freshw. Res. 58:54-66. Crossref

Smith, W. D., J. A. Miller, and S. S. Heppell.

2013. Elemental markers in elasmobranchs: effects of environmental history and growth on vertebral chemistry. PLoS ONE. 8(10):e62423. Crossref

Soriano, M., J. Moreau, J. M. Hoenig, and D. Pauly. 1992. New functions for the analysis of two-phase growth of juvenile and adult fishes, with application to Nile perch. Trans. Am. Fish. Soc. 121:486-493. Crossref

Spieler, R. E., D. P. Fahy, R. L. Sherman, J. A. Sulikowski, and T. P. Quinn.

2013. The yellow stingray, Urobatis jamaicensis (Chondrichthyes: Urotrygonidae): a synoptic review. Caribb. J. Sci. 47:67-97. Crossref

Valenti, S. V., and R. Robertson.

2009. Urotrygon aspidura. The IUCN Red List of Threatened Species 2009: e.T161689A5480775. [Available from website.]

von Bertalanffy, L.

1938. A quantitative theory of organic growth (Inquiries on growth laws. II). Hum. Biol. 10:181-213.

White, W. T., and I. C. Potter.

2005. Reproductive biology, size and age compositions and growth of the batoid Urolophus paucimaculatus, including comparisons with other species of the Urolophidae. Mar. Freshw. Res. 56:101-110. Crossref

White, W. T., and E. Sommerville.

2010. Elasmobranchs of tropical marine ecosystems. In Sharks and their relatives II (J. C. Carrier, J. A. Musick, and M. R. Heithaus, eds.), p. 159-240. CRC Press, Boca Raton, FL.

White, W. T., M. E. Platell, and I. C. Potter.

2001. Relationship between reproductive biology and age composition and growth in Urolophus lobatus (Batoidea: Urolophidae). Mar. Biol. 138:135-147. Crossref

White, W., N. Hall, and I. C. Potter.

2002. Reproductive biology and growth during pre- and postnatal life of Trygonoptera personata and T. mucosa (Batoidea: Urolophidae). Mar. Biol. 140:699-712. Crossref

White, J., C. A. Simpfendorfer, A. J. Tobin, and M. R. Heupel. 2014. Age and growth parameters of shark-like batoids. J. Fish Biol. 84:1340-1353. Crossref 